\title{
Qualidade da forragem de pastagem nativa sob distintas alternativas de manejo ${ }^{(1)}$
}

\author{
Ingrid Heringer(2) e Aino Victor Ávila Jacques(3)
}

\begin{abstract}
Resumo - A queima da vegetação se reflete sobre o solo, a composição botânica, o desenvolvimento das espécies, e também sobre a qualidade da forragem. O objetivo deste trabalho foi estudar cinco sistemas de manejo da pastagem nativa, em relação às queimadas. Foram avaliados os seguintes sistemas, todos pastejados: com queima bienal há mais de 100 anos; sem queima há 32 anos com ou sem roçada; e melhorado há 7 e 24 anos. O delineamento experimental foi o completamente casualizado com três repetições. Os teores de proteína bruta e de digestibilidade in vitro da matéria orgânica foram maiores nas áreas sob melhoramento e roçada. O teor de $\mathrm{N}$ não diferiu entre tratamentos, enquanto os teores de $\mathrm{P}, \mathrm{K}, \mathrm{Ca}$ e Mg foram maiores na forragem da área melhorada, e não diferiram nos demais tratamentos. A quantidade acumulada de nutrientes nos tecidos, reflexo da produção de forragem, foi maior nos sistemas sem queima.
\end{abstract}

Termos para indexação: queimada, melhoramento de pastagem, nutrientes minerais, matéria orgânica, valor nutritivo.

\section{Quality in forage of natural pasture under alternative managements}

\begin{abstract}
Burning of native pasture affects soil, botanical composition, species development, and forage quality. It was studied five management systems of native pasture under grazing condition: biennial burning for more than 100 years; without burning for 32 years with or without mowing; and pasture improvement for 7 and 24 years. The experimental design was a completely randomized one, with three replications. Crude protein and in vitro organic matter digestibility were greater in improved and mowed areas. The level of $\mathrm{N}$ did not differ among treatments, while the levels of $\mathrm{P}, \mathrm{K}, \mathrm{Ca}$ and $\mathrm{Mg}$ were greater in improved area as compared to other treatments. The tissue nutrient quantity accumulated, as result of forage production, was greater in the systems without burning.
\end{abstract}

Index terms: burning, pasture improvement, mineral nutrients, organic matter, nutritive value.

\section{Introdução}

A qualidade da forragem é um dos aspectos básicos determinantes da eficiência da utilização da pastagem. Uma das justificativas pelas quais os produtores queimam seus campos consiste na suposta melhoria na qualidade da forragem, decorrente do

\footnotetext{
(1) Aceito para publicação em 5 de julho de 2001.

Extraído da Tese de Doutorado apresentada pelo primeiro autor à Universidade Federal do Rio Grande do Sul (UFRGS), Porto Alegre, RS. Parcialmente financiado pelo CNPq.

(2) UFRGS, Dep. de Plantas Forrageiras e Agrometeorologia, Caixa Postal 776, CEP 91570-970 Porto Alegre, RS. Bolsista do CNPq. E-mail: renato@prezzotto.com.br

(3) UFRGS, Dep. de Plantas Forrageiras e Agrometeorologia. E-mail: aino@vortex.ufrgs.br
}

rebrote após o fogo. Segundo Svejcar (1989), os principais determinantes das mudanças no valor nutritivo decorrentes da queima são: ação do fogo sobre as espécies dominantes, mudanças na dieta após a queima, ação do fogo na estrutura da vegetação e, especialmente, redução do material morto. Entretanto, tem sido verificado que o aumento na qualidade, em termos de proteína e digestibilidade, é temporário após a queima, e que a forragem volta a perder valor nutritivo após dois a quatro meses (Fontaneli \& Jacques, 1988; Brâncio et al., 1997). Conforme Sacido \& Cauhépé (1998), a maior oferta de Ca, Mg, P e K para as plantas após a queima do pasto pode aumentar temporariamente o teor destes nutrientes nos tecidos verdes, os quais, no entanto, tendem a retornar aos níveis originais após breve período. Isto parece ocorrer porque as plantas sob queima aceleram seu 
ciclo de desenvolvimento, e atingem o estádio reprodutivo antecipadamente, perdendo qualidade (McAtee et al., 1979). Avaliações com animais fistulados evidenciam que o valor nutritivo da dieta selecionada pelos bovinos é semelhante nas áreas com e sem queima (Brâncio et al., 1997), e que os animais são capazes de selecionar forragem de qualidade em meio ao material morto em áreas sem o uso do fogo. Portanto, a queima não é justificada quando se pretende aumentar o valor nutritivo da forragem na pastagem.

Em algumas situações especiais, como em pastagens dominadas por espécies cespitosas grosseiras, resistentes à queima e com grande acumulação de fitomassa, o fogo poderia ser um instrumento útil para controlar as espécies indesejáveis presentes, melhorar a qualidade da dieta, e aumentar a produção animal (Pizzio et al., 1997). Conforme observação desses autores, na Argentina, em pastagem natural dominada por Andropogon lateralis Nees, os ganhos anuais por animal passaram de 76 para $107 \mathrm{~kg}$, a partir do uso da queima anual.

O crescimento das plantas depende de um contínuo suprimento de nutrientes do solo, e cada elemento mineral está envolvido em um movimento cíclico do solo para as plantas, das plantas para os animais, e depois, destes para o solo (Hodgson, 1990), sendo de fundamental importância manejar bem as pastagens para mantê-las produtivas e persistentes. Esse mesmo autor comenta que em pastagens produtivas e bem adubadas da Nova Zelândia há uma extração média anual de $180 \mathrm{~kg} \mathrm{ha}^{-1}$ de N, $20 \mathrm{~kg} \mathrm{ha}^{-1}$ de P e $140 \mathrm{~kg} \mathrm{ha}^{-1} \mathrm{de} \mathrm{K}$, sendo portanto, dependentes de um forte aporte de nutrientes.

O objetivo deste trabalho foi estudar cinco sistemas de manejo da pastagem nativa em relação às queimadas.

\section{Material e Métodos}

Este trabalho foi realizado na região dos Campos de Cima da Serra, no Município de André da Rocha, RS, ao longo de um ano (1997/98), em pastagem natural característica da região. O clima é temperado úmido $(\mathrm{Cfb})$ com verões amenos. O solo das áreas estudadas é um Latossolo Vermelho distroférrico típico, de textura argilosa, com baixa saturação de bases, deficiência de $\mathrm{P}$, teores altos de matéria orgânica e níveis tóxicos de alumínio.

As áreas de pastagem natural estudadas apresentavam- se sob distintos manejos, a saber: sem queima e sem roçada há 32 anos; sem queima e roçada anualmente há 32 anos; melhorada há sete anos (CNM sete anos); melhorada há 24 anos (CNM 24 anos); e queimada há mais de 100 anos numa freqüência bienal sendo todas as áreas pastejadas. O delineamento experimental foi o inteiramente casualizado com três repetições.

Em todos os tratamentos sem queima, o pastejo foi o rotativo, baseado na oferta de forragem, com o período de pastejo variando de acordo com a disponibilidade de forragem. A área do tratamento com queima permaneceu com lotação contínua durante todo o ano. A queima era realizada ao final do inverno e início da primavera, a cada dois anos.

O solo da área melhorada há 24 anos, em 1973, recebeu preparo convencional, calagem e adubação, tendo sido semeada aveia-amarela (Avena byzantina Koch) para produção de sementes. Em 1974, essa área foi gradeada, adubada, e feita semeadura de festuca (Festuca elatior Schreb.) e trevo-branco (Trifolium repens L.). Em 1984, foi roçada e gradeada, e recebeu $3 \mathrm{t} \mathrm{ha}^{-1}$ de calcário dolomítico, quando foi semeado trevo-branco e trevo-vermelho (T. pratense L.). A partir de 1984, foram aplicados superficialmente, na área, de 2 a 3 t ha-1 de calcário dolomítico, sem revolvimento do solo, a cada 4 a 5 anos, e realizadas adubações anuais de manutenção com $200 \mathrm{~kg} \mathrm{ha}^{-1}$ das fórmulas 10-30-10 ou 5-30-15. No período de 1995 a 1997 a adubação de manutenção foi reduzida a $100 \mathrm{~kg} \mathrm{ha}^{-1} \mathrm{ano}^{-1}$ da fórmula 5-30-15.

A área com sete anos de melhoramento do campo nativo recebeu, em 1990, preparo superficial com grade niveladora, a uma profundidade média de 4 a $5 \mathrm{~cm}$, aplicação superficial de calcário $\left(3 \mathrm{t} \mathrm{ha}^{-1}\right)$ e $200 \mathrm{~kg} \mathrm{ha}^{-1}$ de 5-30-15. Em 1991, foi feita a introdução de trevo-branco e de trevo-vermelho nessa área. As demais práticas de manejo seguem o mesmo manejo do CNM 24 anos.

Os sítios escolhidos foram de $10 \times 30 \mathrm{~m}$, situados topograficamente numa encosta de cada piquete, cuja situação é a mais representativa do relevo da região. Em cada sítio foram locadas três gaiolas de exclusão ao pastejo.

A avaliação da qualidade da forragem ocorreu ao longo de um ano, e as amostras foram coletadas dentro das gaiolas de exclusão ao pastejo. No interior de cada gaiola foi delimitada metade da área, para avaliação da pastagem a cada 45 dias (dois cortes na estação), e a outra metade, para avaliação, a cada 90 dias (simulando um diferimento da pastagem na estação). As gaiolas foram removidas de local, sempre representando a condição do sítio, a cada início de estação, após emparelhamento da vegetação onde elas foram locadas. Os cortes das amostras foram realizados a $5 \mathrm{~cm}$ de altura acima do nível do solo. O material 
cortado foi colhido de um quadrado de $0,25 \mathrm{~m}^{2} \mathrm{e}$ acondicionado em sacos de polietileno. No laboratório, as amostras foram separadas, descartando-se destas o material senescente e espécies indesejáveis. Este material foi seco em estufa com circulação forçada de ar até peso constante, o que resultou na matéria seca da forragem verde (MSFV), e moído em moinho tipo Willey, com malha de $1 \mathrm{~mm}$. A seguir, as amostras foram acondicionadas em sacos de polietileno e encaminhadas ao Laboratório de Nutrição Animal da Empresa de Pesquisa Agropecuária e Difusão de Tecnologia de Santa Catarina (Epagri), da Estação Experimental de Lages, SC. O teor de proteína (PB) foi estimado através do teor de $\mathrm{N}$ total da forragem, e o de digestibilidade in vitro da matéria orgânica (DIVMO), pelo método de Tilley \& Terry (1963), modificado por Freitas (1991), para forragens de baixa qualidade. Os dados de proteína bruta e DIVMO apresentados são os valores médios encontrados para a freqüência de cortes de 45 e 90 dias.

As avaliações dos teores de proteína bruta e de DIVMO foram realizadas em todos os tratamentos, enquanto os de $\mathrm{N}, \mathrm{P}, \mathrm{K}, \mathrm{Ca}$ e $\mathrm{Mg}$ na forragem foram feitos somente para os tratamentos sem queima e sem roçada há 32 anos, CNM sete anos e queimado há mais de 100 anos, na freqüência de cortes de 90 dias, em função do custo das análises. As determinações foram feitas segundo Tedesco et al. (1995). $\mathrm{O}$ acúmulo de nutrientes nos tecidos foi estimado multiplicando-se os teores de nutrientes na forragem pela quantidade anual de forragem acumulada.

Os resultados foram submetidos à analise de variância e as médias foram comparadas a $\mathbf{5 \%}$ de probabilidade pelo teste de Waller-Duncan (efeitos principais) e pelo teste de Student (interações).

\section{Resultados e Discussão}

Houve interação significativa entre tratamentos e estações do ano para os teores de $\mathrm{PB}(\mathrm{P}<0,05)$, os quais na primavera e verão geralmente foram maiores nos tratamentos melhorados, intermediário no sem queima e roçado, e inferiores no sem queima e sem roçada, e no queimado (Figura 1). No outono e inverno, foram superiores nos melhorados e no sem queima e roçada, e inferiores no sem queima e sem roçada e no queimado $(\mathrm{P}<0,05)$. Os teores de $\mathrm{PB}$ dos tratamentos melhorados e sem queima e roçada foram similares, e tiveram o mesmo comportamento ao longo do ano. A área queimada apresentou teores de PB inferiores aos obtidos nos outros tratamentos durante a estação quente, porém, sendo semelhante ao tratamento sem queima e sem roçada no período frio $(\mathrm{P}<0,05)$. A maior qualidade da forragem dos tratamentos melhorados e roçado justifica-se pela contribuição nestas áreas de Paspalum notatum Fl., P. paniculatum L., P. dilatatum Poir., P. urvillei Steud., Desmodium incanum DC., D. triarticulatum Malme., e de festuca e trevos introduzidos nessas áreas melhoradas.

Os valores médios de $\mathrm{PB}$ dos tratamentos sem queima e queimado são semelhantes aos observados por Maraschin et al. (1996) na forragem de pastagem nativa na Depressão Central, que foram de 8,8 a $11,1 \%$, e também semelhantes aos das pastagens nativas do Uruguai, com amplitude de 6 a 15\% (Berreta et al., 1999), variando conforme a estação do ano, composição botânica e quantidade de material morto.

Quanto às estações, o nível de PB decresceu na seguinte ordem: inverno, outono, primavera e verão, o que está de acordo com observações de Berreta (1996). Berreta (1996) constatou que os valores máximos de PB do campo nativo ocorrem durante o inverno e início da primavera, enquanto o mínimo é registrado no verão. No inverno, tanto espécies estivais como hibernais estão em estádio vegetativo, enquanto no verão as espécies já floresceram, ou estão em distintos graus de maturidade, perdendo qualidade. Lemaire \& Chapman (1996) relatam que o crescimento depende do acúmulo de temperatura, e que quanto maior, mais rapidamente os tecidos estarão maduros, maior será a translocação de nutrientes e, conseqüentemente, a perda do valor nutritivo.

Quanto aos níveis de DIVMO da forragem, também houve interação entre tratamentos e estações do ano $(\mathrm{P}<0,05)$. Na primavera e verão, a DIVMO foi inferior no tratamento queimado. No outono e inverno, a DIVMO do tratamento queimado foi semelhante à obtida no tratamento sem queima e sem roçada, e ambos são inferiores aos resultados alcançados nos demais tratamentos. Os níveis de DIVMO em todos os tratamentos foram inferiores no verão e outono (Figura 1).

Os baixos níveis de proteína e digestibilidade no tratamento queimado, correspondente ao verão (Figura 1), provavelmente, devem-se à baixa qualidade das espécies forrageiras que dominaram a área, e ao ritmo de desenvolvimento destas, com muitos componentes atingindo a maturidade precocemente.

Na média dos tratamentos, a digestibilidade foi 
maior nos tratamentos melhorados e no sem queima e roçado, intermediária no sem queima e sem roçada e inferior no queimado. A digestibilidade muito semelhante entre os tratamentos melhorado há sete anos e sem queima e roçada (Figura 1) provavelmente é devido ao amplo predomínio de P. notatum, sobretudo o biótipo André da Rocha, uma espécie nativa de boa qualidade, cujo valor agronômico e ecológico precisa ser mais estudado. A digestibilidade na área queimada e na sem queima e sem roçada assemelha-se à observada por Maraschin et al. (1996) em pastagem natural, de 46,8 a 52,5\% na fração verde da pastagem. Já os valores de digestibilidade das áreas melhoradas e sem queima e roçada assemelham-se mais aos das pastagens nativas do Uruguai, com média de 58\% (Berreta et al., 1999).
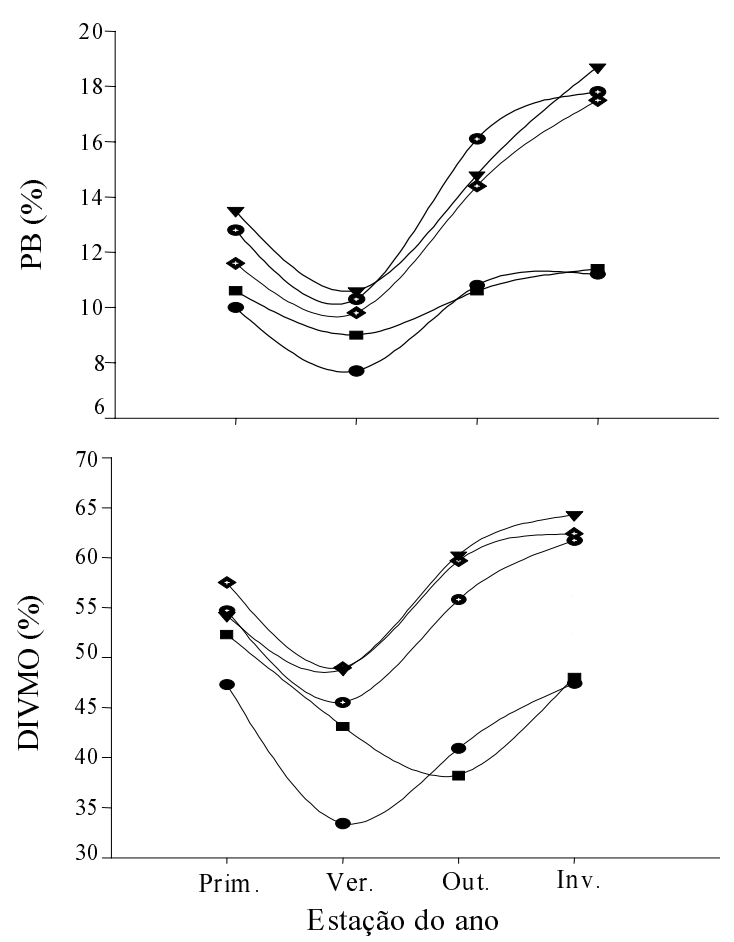

Figura 1. Teores de proteína bruta (PB) e digestibilidade in vitro da matéria orgânica (DIVMO) na matéria seca da forragem de uma pastagem natural sem queima e sem roçada (ם), sem queima e roçada $(\square)$, melhorada há $24(\bullet)$ e a 7 anos (O), e com queima bienal há mais de 100 anos $(\boldsymbol{\Lambda})$, e conforme a estação do ano.
Houve efeito significativo $(\mathrm{P}<0,05)$ da freqüência de corte sobre os teores de PB e de DIVMO, sendo, respectivamente, de 13,5 e $53,4 \%$ no intervalo de corte de 45 dias, e de 11,5 e $49,0 \%$ no de 90 dias. Isto ocorre porque, com o desenvolvimento das plantas, há uma acentuada mudança na relação folha/caule, aumento na quantidade de tecidos de sustentação, e proporcionalmente menos $\mathrm{N}$, em decorrência da maior maturidade dos tecidos da planta (Hodgson, 1990; Lemaire et al., 1995).

Os parâmetros de qualidade avaliados indicam que a forragem das áreas melhoradas e sem queima e roçada não apresenta limitação para a produção de bovinos de maior requerimento nutricional (DIVMO acima de 55\%), à exceção do verão, em que a menor digestibilidade pode limitar o consumo (Conrad et al., 1964). Os animais, por sua capacidade de seleção, podem colher forragem de maior qualidade que a estimada nestas análises, sempre que a diversidade de espécies e massa de forragem permitirem boa oportunidade para escolha de uma dieta de alta qualidade (Berreta, 1996).

Quanto ao teor de nutrientes minerais na forragem, verificou-se efeito significativo $(\mathrm{P}<0,05)$ dos tratamentos sobre todos os minerais analisados, à exceção do nitrogênio. Os teores de nutrientes foram maiores no tratamento melhorado em relação ao sem queima e sem roçada e ao queimado (Figura 2). Embora não-significativa, a tendência para $\mathrm{N}$ também é a mesma dos demais nutrientes.

Os teores médios de $\mathrm{N}$ nos tecidos variaram de 1,14 a $1,69 \%$ entre os tratamentos, e não apresentaram efeito de estação do ano $(\mathrm{P}>0,05)$, mas tendência de níveis maiores durante o inverno (Figura 2). $\mathrm{O}$ teor de $\mathrm{N}$ nos tecidos aumenta com a área foliar efetiva da pastagem, e decresce com o aumento da biomassa (Lemaire et al., 1995), portanto, devendo sofrer redução na primavera e verão quando há maior acúmulo de forragem. O declínio no teor de $\mathrm{N}$ ocorre como resultado do aumento na proporção de componentes estruturais, que possuem baixo conteúdo desse nutriente (Lemaire et al., 1995).

$\mathrm{O}$ teor médio de $\mathrm{P}$ na forragem variou de $0,13 \mathrm{a}$ $0,26 \%$, entre tratamentos, sendo o dobro na área melhorada em relação às sem melhoramento. Os níveis médios de $\mathrm{P}$, na área sem queima e sem roçada $\mathrm{e}$ na queimada, estão dentro da amplitude referida por 

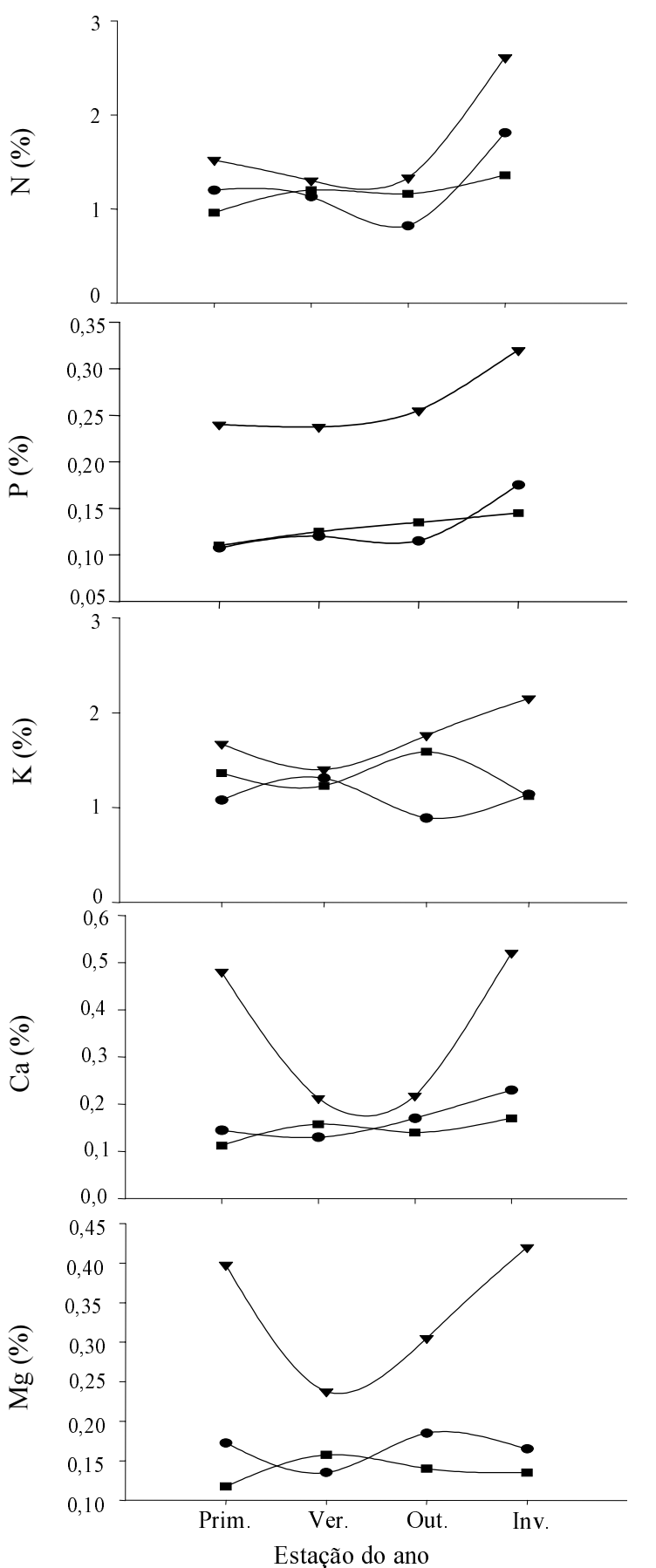

Figura 2. Teores de N, P, K, Ca e Mg na matéria seca da forragem de uma pastagem natural sem queima e sem roçagem (অ), melhorada há 7 anos $(\boldsymbol{\nabla})$ e com queima bienal há mais de 100 anos ( ), e conforme a estação do ano.
Senger et al. (1996), de 0,06 a 0,19\%, em pastagens naturais não-adubadas, oriundas de onze unidades de mapeamento de solo no Estado do Rio Grande do Sul. A concentração de $\mathrm{P}$ na forragem apresentou efeito significativo de estações do ano, e foi maior no inverno $(0,21 \%)$, em relação às demais épocas (média de $0,16 \%$ ) (Figura 2). Os menores teores de $\mathrm{P}$ alcançados durante a estação quente devem-se à maior velocidade de crescimento, resultando na formação de tecidos maduros, com decréscimo nas taxas de consumo de $\mathrm{P}$, o que pode ser atribuído ao reduzido influxo pelas raízes velhas e suberizadas (Bavera \& Bocco, 1987). As maiores concentrações de $\mathrm{P}$ nos tecidos das plantas da área melhorada devem-se não somente à maior quantidade de $\mathrm{P}$ no solo, mas também ao efeito do calcário no aumento da solubilidade e disponibilidade desse nutriente para as plantas (McCray \& Sumner, 1990).

Houve efeito positivo da adubação sobre as concentrações de $\mathrm{K}$ na forragem, que foram maiores na área melhorada, com média de $1,74 \%$, e inferiores no tratamento sem queima e sem roçada $(1,32 \%)$ e no queimado $(1,10 \%)$, os quais estão dentro da amplitude referida por Senger et al. (1996) em relação às pastagens naturais, de 0,44 a $1,81 \%$. Somente na pastagem natural melhorada, os níveis de K mostraram tendência de serem superiores no outono e inverno em relação às demais épocas (Figura 2), os quais geralmente decrescem com o avanço da idade da planta (Senger et al., 1996).

Os níveis médios de Ca na forragem variaram de 0,15 a $0,36 \%$, entre tratamentos, sendo maiores na área melhorada $(\mathrm{P}<0,05)$. Maiores teores de $\mathrm{Ca}$ nos tecidos vegetais são reflexo do Ca trocável do solo, e das maiores concentrações de N e P no solo (Spears, 1994). Somente houve efeito das estações do ano sobre os teores de $\mathrm{Ca}$ na forragem do tratamento melhorado $(\mathrm{P}>0,05)$, os quais foram maiores na primavera e inverno em relação às demais estações (Figura 2).

O teor médio de $\mathrm{Mg}$ variou de 0,14 a 0,34\%, entre tratamentos, sendo maior na pastagem nativa melhorada $(\mathrm{P}<0,05)$. A concentração desse nutriente nas pastagens naturais das regiões fisiográficas da Depressão Central e Campanha do Estado do Rio Grande do Sul está entre 0,06 e $0,15 \%$ (Senger et al., 1996), portanto, assemelhando-se aos 
valores encontrados neste trabalho na pastagem nativa sem melhoramento. $\mathrm{O}$ teor de $\mathrm{Mg}$ na forragem não foi alterado no decorrer das estações $(\mathrm{P}>0,05)$, e de maneira semelhante ao $\mathrm{Ca}$, tende a ser maior durante a estação fria (Figura 2).

O estádio de maturidade afeta o conteúdo de uma série de minerais nas pastagens. Geralmente, o conteúdo de N, P e K decresce com a idade ou órgão da planta, enquanto o teor de $\mathrm{Ca}$ e $\mathrm{Mg}$ freqüentemente aumenta (Bavera \& Bocco, 1987; Spears, 1994). As flutuações nos teores de nutrientes na forragem foram mais evidentes na pastagem natural melhorada, com tendência a serem superiores no inverno (e primavera para $\mathrm{Ca}$ e $\mathrm{Mg}$ ) em relação às demais épocas (Figura 2). Os níveis de P, K, Ca e Mg na área melhorada foram superiores aos demais tratamentos, e refletiram a maior fertilidade do solo, como conseqüência da correção e adubação do solo da pastagem.

De uma maneira geral, a concentração de nutrientes nos tecidos vegetais não foi alterada pela queima. As plantas da área queimada produziram menos, porém mantiveram teores de nutrientes minerais nos tecidos similares ao da área sem queima e sem roçada. Por outro lado, Sacido \& Cauhépé (1998) verificaram que em pastagem de Paspalum quadrifarium, caracterizada como grosseira, após a queima houve aumento na disponibilidade de $\mathrm{P}, \mathrm{K}, \mathrm{Ca}$ e $\mathrm{Mg}$ nas plantas. Porém, os acréscimos nos teores de nutrientes também foram temporários, com o $\mathrm{N}$ passando de $0,64 \%$ para $1,92 \%$, e o P de $0,05 \%$ para $0,23 \%$, na primeira amostragem pós-queima, mas que retornaram aos valores originais após oito meses.

Houve efeito significativo de tratamentos e estações do ano $(\mathrm{P}<0,05)$ na quantidade média de $\mathrm{N}$ acumulado. Na média das estações, o acúmulo de $\mathrm{N}$ foi maior nos tratamentos sem queima e sem roçada e no melhorado, com média de $29,2 \mathrm{~kg} \mathrm{ha}^{-1}$, e de $9,3 \mathrm{~kg} \mathrm{ha}^{-1}$ no tratamento com queima há mais de 100 anos (Figura 3). Na primavera e verão, os acúmulos desse nutriente nestes tratamentos foram superiores (média de $36,8 \mathrm{~kg} \mathrm{ha}^{-1}$ ) aos de outono e inverno (média de 9,0 kg ha-1).

A quantidade média estacional de $\mathrm{P}$ acumulado na forragem apresentou interação significativa $(\mathrm{P}<0,05)$ entre tratamentos e estações do ano. Durante a estação quente o acúmulo de $\mathrm{P}$ foi superior

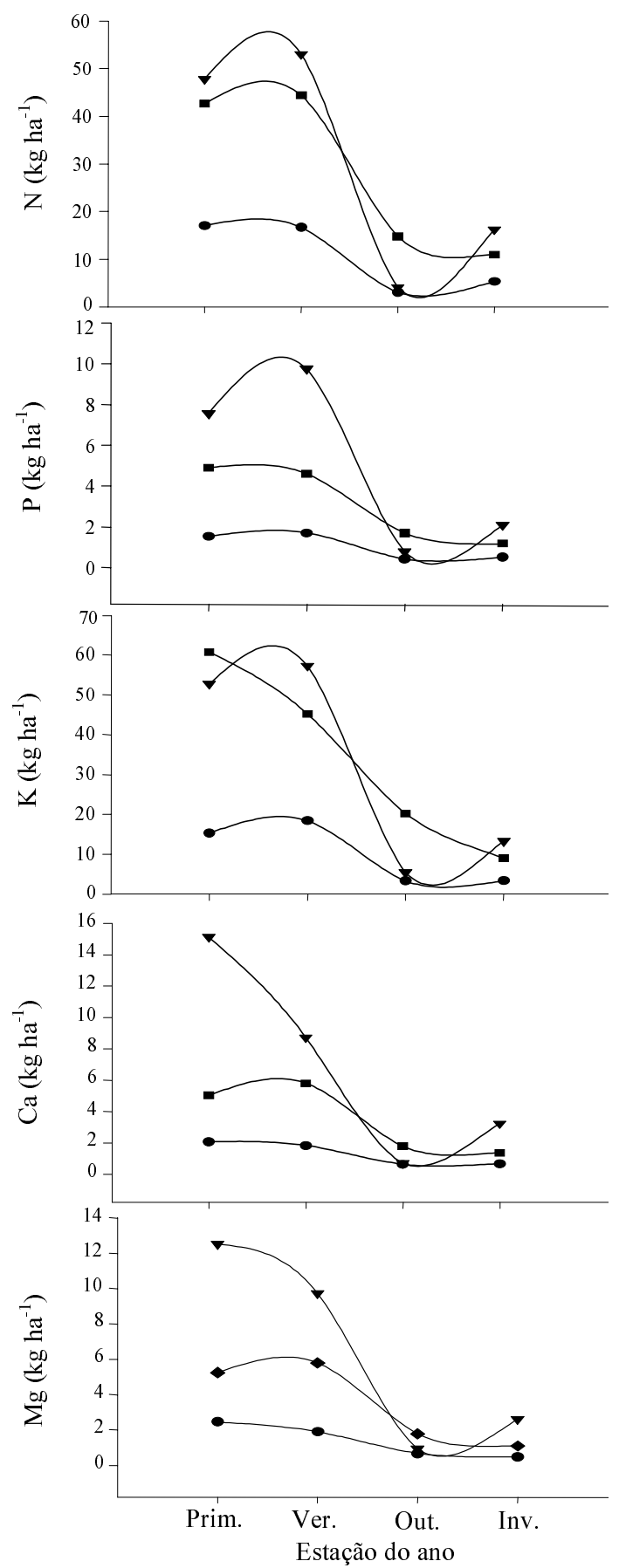

Figura 3. Quantidade de N, P, K, Ca e Mg na matéria seca da forragem de uma pastagem natural sem queima e sem roçagem $(\boldsymbol{\square})$, melhorada há 7 anos $(\boldsymbol{\nabla})$ e com queima bienal há mais de 100 anos (0), e conforme a estação do ano. 
no tratamento melhorado $\left(8,65 \mathrm{~kg} \mathrm{ha}^{-1}\right)$ e sem queima e sem roçada $\left(4,76 \mathrm{~kg} \mathrm{ha}^{-1}\right)$, em relação ao do outono e inverno (1,44 $\left.\mathrm{kg} \mathrm{ha}^{-1}\right)$ (Figura 3). No tratamento queimado, não houve diferença entre estações ao longo de todo o ano (média de 1,04 kg ha-1). Na primavera e verão, o acúmulo de $\mathrm{P}$ foi maior na área melhorada, seguido do sem queima e sem roçada, e do tratamento queimado, e não houve diferença entre tratamentos nas demais estações do ano $(\mathrm{P}>0,05)$.

Quanto ao acúmulo estacional de K na forragem, houve efeito simples de tratamentos e estações do ano $(\mathrm{P}<0,05)$, sendo superior no sem queima e sem roçada e no melhorado, com média de $33 \mathrm{~kg} \mathrm{ha}^{-1}$, e inferior no queimado, com média de $10 \mathrm{~kg} \mathrm{ha}^{-1}$. Em relação às estações, o acúmulo de $\mathrm{K}$ foi superior na primavera e verão, com média aproximada de $42 \mathrm{~kg} \mathrm{ha}^{-1}$, e inferior na estação fria, com média de $9 \mathrm{~kg} \mathrm{ha}^{-1}$ (Figura 3 ).

A quantidade média acumulada de $\mathrm{Ca}$ na forragem apresentou interação entre tratamentos e estações do ano $(\mathrm{P}<0,05)$. Na primavera, o acúmulo de $\mathrm{Ca}$ foi superior na pastagem nativa melhorada $\left(15,12 \mathrm{~kg} \mathrm{ha}^{-1}\right)$ em relação à sem queima e sem roçada $\left(5,01 \mathrm{~kg} \mathrm{ha}^{-1}\right)$ e à queimada $\left(2,06 \mathrm{~kg} \mathrm{ha}^{-1}\right)$, que foram semelhantes (Figura 3). No verão, o acúmulo de $\mathrm{Ca}$ foi maior nos tratamentos sem queima e sem roçada e no melhorado (média de 7,26 kg ha-1), em relação ao queimado $\left(1,83 \mathrm{~kg} \mathrm{ha}^{-1}\right)$. Os tratamentos não diferiram na estação fria. Entre estações, a quantidade acumulada de Ca só não variou no tratamento queimado. O acúmulo de Ca na área sem queima e sem roçada foi maior na primavera e verão $\left(5,41 \mathrm{~kg} \mathrm{ha}^{-1}\right)$, em relação à estação fria $\left(1,58 \mathrm{~kg} \mathrm{ha}^{-1}\right)$. $\mathrm{Na}$ área melhorada, foi maior na primavera $\left(15,12 \mathrm{~kg} \mathrm{ha}^{-1}\right)$, seguida do verão $\left(8,72 \mathrm{~kg} \mathrm{ha}^{-1}\right)$ e inferior no outono e inverno com média de $1,95 \mathrm{~kg} \mathrm{ha}^{-1}$.

$\mathrm{O}$ acúmulo estacional de $\mathrm{Mg}$ na forragem também apresentou interação entre tratamentos e estações do ano $(\mathrm{P}<0,05)$. $\mathrm{O}$ acúmulo de $\mathrm{Mg}$ na primavera foi superior na área melhorada $\left(12,52 \mathrm{~kg} \mathrm{ha}^{-1}\right)$ em relação à área sem queima e sem roçada e à queimada (média de 3,85 kg ha-1) (Figura 3). No verão, foi maior no tratamento melhorado $\left(9,74 \mathrm{~kg} \mathrm{ha}^{-1}\right)$, intermediário no sem queima e sem roçada $\left(5,80 \mathrm{~kg} \mathrm{ha}^{-1}\right) \mathrm{e}$ menor no tratamento queimado $\left(1,91 \mathrm{~kg} \mathrm{ha}^{-1}\right)$. Nas demais estações, os tratamentos não diferiram entre si $(\mathrm{P}>0,05)$. Dentro do tratamento sem queima e sem roçada o acúmulo de $\mathrm{Mg}$ foi maior na primavera e verão $\left(5,52 \mathrm{~kg} \mathrm{ha}^{-1}\right)$, intermediário no outono $\left(1,78 \mathrm{~kg} \mathrm{ha}^{-1}\right)$ e inferior no inverno $\left(1,09 \mathrm{~kg} \mathrm{ha}^{-1}\right)$. No CNM sete anos, foi maior na primavera e verão $\left(11,13 \mathrm{~kg} \mathrm{ha}^{-1}\right)$ em relação à estação fria $\left(1,78 \mathrm{~kg} \mathrm{ha}^{-1}\right)$, enquanto não diferiram entre estações no tratamento queimado (média de $1,38 \mathrm{~kg} \mathrm{ha}^{-1}$ ).

Como um reflexo maior do acúmulo de forragem em cada tratamento e do ciclo de produção da pastagem natural, a flutuação anual no acúmulo de nutrientes minerais tende a se aproximar entre os tratamentos que não foram queimados (sem queima e sem roçada e campo nativo melhorado há sete anos).

Os resultados do acúmulo de nutrientes na forragem são expressivos, principalmente no substrato pastagem natural, usualmente considerado pouco produtivo e de baixa qualidade, quando comparado às pastagens cultivadas. Na pastagem nativa houve um grande volume de nutrientes disponíveis para o consumo animal e/ou para senescer e retornar ao solo mediante reciclagem.

A qualidade da forragem, juntamente com vários outros aspectos levantados nas áreas sem queima, relevam as grandes possibilidades de aumento na produção animal com poucos investimentos, sem agredir o meio, e com manejo mais racional. O uso de fertilizantes é uma alternativa tecnológica muito eficaz para aumentar a produção de forragem e o valor nutritivo das pastagens naturais que, juntamente com a introdução de leguminosas, previne a degradação e melhora a maneira sustentável de uso deste recurso natural, sem destruir a vegetação (Berreta et al., 1999).

\section{Conclusões}

1. A aplicação de calcário e fertilizantes, a introdução de espécies e a roçada melhoram a qualidade da forragem.

2. A queima da pastagem natural não melhora a qualidade da forragem, que é semelhante à de áreas sem queima e sem roçada e só pastejadas.

3 . Os teores de nutrientes minerais na forragem são maiores em pastagem nativa melhorada pela aplicação de calcário e fertilizantes.

4. A queima da pastagem nativa reduz a quantidade de nutrientes minerais presentes na forragem. 


\section{Referências}

BAVERA, G. A.; BOCCO, O. A. Suplementación mineral del bovino. Buenos Aires: Hemisferio Sur, 1987. 88 p.

BERRETTA, E. J. Campo natural: valor nutritivo y manejo. In: RISSO, D. F.; BERRETTA, E. J.; MORÓN, A. (Ed.). Producción y manejo de pasturas. Montevideo: Instituto Nacional de Investigación Agropecuaria, 1996. p. 113127. (Serie Técnica, 80).

BERRETTA, E. J.; RISSO, D. F.; MONTOSSI, F.; PIGURINA, G. Problems of animal production related to pastures in South America: Uruguay. In: GRASSLAND ECOPHYSIOLOGY AND GRAZING ECOLOGY INTERNATIONAL SYMPOSIUM, 1999, Curitiba. Proceedings... Curitiba: UFPR, 1999. p. 49-65.

BRÂNCIO, P. A.; NASCIMENTO JÚNIOR, D.; MORAES, E. A.; REGAZZI, A. J.; LEITE, G. C. Avaliação de pastagem nativa dos cerrados submetida à queima anual. 2. Qualidade da dieta de bovinos. Revista Brasileira de Zootecnia, Viçosa, v. 26, n. 3, p. 438-442, 1997.

CONRAD, H. R.; PRATT, A. D.; HIBBS, J. W. Regulation of feed intake in dairy cows. I. Change in importance of physical and physiological factors with increasing digestibility. Journal Dairy Science, Champaign, v. 47, p. 54-62, 1964.

FONTANELI, R. S.; JACQUES, A. V. A. Melhoramento de pastagem natural: ceifa, queima, diferimento e adubação. Revista Brasileira de Zootecnia, Viçosa, v. 17, n. 12, p. 180-194, 1988.

FREITAS, E. G. Avaliação in vitro de forragens de baixa qualidade. In: REUNIẨO DO GRUPO TECNICO REGIONAL DO CONE SUL (ZONA CAMPOS) EM MELHORAMENTO E UTILIZAÇÃO DE RECURSOS FORRAGEIROS DAS ÁREAS TROPICAL E SUBTROPICAL, 12., 1991, Bagé. Anais... Bagé: Embrapa, 1991. p. 39-51.

HODGSON, J. Grazing management: science into practice. New York: Longman Scientific and Technical, 1990. $203 \mathrm{p}$.

LEMAIRE, G.; CHAPMAN, D. Tissue flows in grazed plant communities. In: HODGSON, J.; ILLIUS, A. W. (Ed.). The ecology and management of grazing systems. Wallingford: CAB, 1996. p. 3-36.

LEMAIRE, G.; GASTAL, F.; PLENET, D. Dynamics of N uptake and $\mathrm{N}$ distribution in plant canopies: use of crop $\mathrm{N}$ status index in crop modeling. In: LEMAIRE, G.; BURNS, I. G. (Ed.). Diagnostic procedures for crop $\mathbf{N}$ management. Poitiers: Institut National de la Recherche Agronomique, 1995. p. 15-29. (Les Colloques, 82).
McATEE, J. W.; SCIFRES, C. J.; DRAWE, D. L. Digestible energy and protein content of gulf cordgrass following burning or shredding. Journal of Range Management, Denver, v. 32, n. 5, p. 376-378, 1979.

McCRAY, J. M.; SUMNER, M. E. Assessing and modifying $\mathrm{Ca}$ and $\mathrm{Al}$ levels in acid subsoils. Advances in Soil Science, New York, v. 14, p. 45-75, 1990.

MARASCHIN, G. E.; APEZTEGUIA, E. S.; GOMES, K. E. Avaliação do potencial produtivo de pastagens naturais da depressão central do Rio Grande do Sul. In: REUNIÃO DO GRUPO TÉCNICO REGIONAL DO CONE SUL (ZONA CAMPOS) EM MELHORAMENTO E UTILIZAÇÃO DE RECURSOS FORRAGEIROS DAS ÁREAS TROPICAL E SUBTROPICAL, 16., 1996, Porto Alegre. Anais... Porto Alegre:UFRGS/Emater/Fao/ Fepagro, 1996. p. 90-91.

PIZZIO, R.; PALLARÉS, O. R.; FERNÁNDEZ, J. G. Pasturas subtropicales en campos bajos de corrientes. Mercedes: INTA, 1997. 4 p. (Noticias y comentarios, 321).

SACIDO, M.; CAUHÉPÉ, M. Calidad de los rebrotes postquema en pajonales de Paspalum quadrifarium. In: REUNIÓN DEL GRUPO TÉCNICO REGIONAL DEL CONO SUR EN MEJORAMIENTO Y UTILIZACIÓN DE LOS RECURSOS FORRAJEROS DEL AREA TROPICAL Y SUBTROPICAL, 24., 1998, Montevideo. Anais... Montevideo: Instituto Nacional de Investigación Agropecuaria, 1998. p. 73-85. (Serie Técnica, 94).

SENGER, C. C. D.; SANCHEZ, L. M. B.; PIRES, M. B. G.; KAMINSKI, J. Teores minerais em pastagens do Rio Grande do Sul. I. Cálcio, fósforo, magnésio e potássio. Pesquisa Agropecuária Brasileira, Brasília, v. 31, n. 12, p. 897-904, dez. 1996.

SPEARS, J. W. Minerals in forages. In: FAHEY JUNIOR, G. C.; MOSER, L. E.; MERTENS, D. R.; COLLINS, M. (Ed.). Forage quality, evaluation and utilization. Lincoln: Academic, 1994. p. 281-317.

SVEJCAR, T. J. Animal performance and diet quality as influenced by burning on tallgrass prairie. Journal of Range Management, Denver, v. 42, n. 1, p. 11-15, 1989.

TEDESCO, M. J.; GIANELLO, C.; BISSANI, C. A.; BOHNEN, H.; VOLKWEISS, S. J. Análise de solo, plantas e outros materiais. 2. ed. Porto Alegre: UFRGS, 1995. 174 p. (Boletim Técnico de Solos, 5).

TILLEY, J. M. A.; TERRY, R. A. A two-stage technique for the "in vitro" digestion of forage crops. Journal of the British Grassland Society, Oxford, v. 18, p. 104-111, 1963. 